\title{
Mechanical Behaviour of Reinforced Sand with Natural Curauá Fibers through Full Scale Direct Shear Tests
}

\author{
Leila Maria Coelho de Carvalho ${ }^{1, *}$, Michelé Dal Toé Casagrande ${ }^{1}$ \\ ${ }^{1}$ University of Brasília, Civil and Environmental Engineering Department, Brazil
}

\begin{abstract}
Inclusion of natural fibers (sisal, curauá, coco fiber and others) for soil improvement has been the study object in diverse geotechnical areas and it is a topic of growing interest, within the research area of new geotechnical materials. The state of the art in this subject highlights excellent results as soil strength parameters improve and post-cracking strength (toughness) increase. Soil reinforcement technique with fibers is established in the technology of composite materials, this being a combination of two or more materials presenting properties that the component materials do not possess on their own. The aim of this paper is to study the mechanical behaviour of sand-fiber composite by inserting natural curauá fibers into a sandy matrix, with different fiber contents. The fibers were randomly distributed in the soil mass. The experimental program included physical and mechanical characterization of the composites, using full-scale direct shear tests, with samples measuring $30 \times 30 \mathrm{~cm}$ and $15 \mathrm{~cm}$ high. Direct shear tests were carried out using fibers with $25 \mathrm{~mm}$ length and 0.5 and $0.75 \%$ fiber content (relative to the soil dry weight). The specimens also presented a relative density of $50 \%$ and moisture content of $10 \%$. It was sought to establish a pattern behaviour so that the addition of curauá fiber influence can be explained, thus, comparing with the sandy soil shear strength parameters. Inclusion of natural curauá fibers as soil reinforcement presented satisfactory results, as an increase in the soil shear strength parameters was observed when compared with sandy soil results.
\end{abstract}

\section{Introduction}

The application of alternative materials for the reinforcement of soils is a growing theme of interest in the various areas of engineering. Humankind has used the technique of improving the mechanical properties of soils with the addition of fibers for a long time, but it was only after the second half of the 20th century that several works were published with the interest of analysing the vegetable fibers addition effect in order to improve the mechanical behaviour of soils. The main idea of soil reinforcement is to obtain an improvement in soil shear strength parameters. The concept of reinforced soil was developed in the 1960s by the French engineer Henri Vidal. The engineer patented one of his discoveries, the "reinforced earth", where he proved that the soil shear strength improved when introducing a reinforcement element in the soil matrix [8].

Several types of fibers that are used in the world can be divided in two major groups: synthetic fibers composed of artificial materials, which has advantages such as well-defined mechanical properties and resistance to weathering. Natural fibers, mostly of vegetal origin (organic), present inconstant physical characteristics (diameter and length), but still provide good results as soil reinforcement. However, those fibers are subject to biological degradation. A growing interest in the use of new materials as soil reinforcement is observed, since plant fibers are good options due to their low cost and high availability. Several authors have reported in their work some changes that occur in the mechanical behaviour of fiber-reinforced soils $[6,7,11,12,15]$. These changes are related to compaction, shear strength, deformability, rupture mode, volumetric variation, initial stiffness and hydraulic conductivity.

The technique of reinforcing soils with fibers is established in the technology of composite materials, this being a combination of two or more materials having properties that the component materials do not possess on their own. Thus, these are formed by a matrix (soil, concrete, mortar) and by the reinforcing element (fibers, steel and others). The improvement or alteration of the mechanical properties of the fiber-reinforced soils depends on the characteristics of the soil (size, shape and particle size, void index, etc.), fibers (tensile strength, elasticity modulus, length, content and roughness), confining stress and loading type. Thus, there are various types of soil reinforcement fibers, each with distinct behaviour characteristics, i.e., different physical and mechanical properties. It is necessary to understand the matrix-reinforcement interaction mechanisms and their contribution in the composite material behaviour, in order to define the best type of reinforcement (fiber) to be used.

Plant fibers when compared to synthetic fibers, are inexpensive, easy to obtain, widely available, easier to handle, present good mechanical properties, do not generate excessive amounts of waste, employ relatively simple technologies and require less energy in the

* Corresponding author: leila.mariacarvalho@hotmail.com 
production process, besides being made from renewable sources [5]. However, plant fibers present great variability of physical and mechanical properties (about 40\%), susceptibility to degradation in natural environments and dimensional variations due to changes in moisture content and temperature [7]. The development of fiber-reinforced composite materials is largely motivated by environmental awareness growth due to problems related to waste disposal and depletion of petrochemical resources [7]. Curauá is among the most competitive and economically viable fibers [16]. Due to its characteristics, curauá fiber has also aroused the interest of the automotive industry being used as a reinforcing agent in front panels, package carriers, side doors and vehicle trunks that are part of the sector's portfolio of giants, such as Volkswagen, Honda and General Motors [16].

According to Oliveira [9], each plant of curauá produces about 24 leaves and the yield of dry fiber is approximately $6 \%$, totalling almost $2 \mathrm{~kg}$ of fiber per plant. One hectare produces $3,600 \mathrm{~kg}$ of dry fiber a year, although these values vary greatly. Several works in recent years were developed using the curauá fiber as soil reinforcement [6, 12, 17, 18]. Pinto [12] studied the behaviour of curauá and sisal fibers as reinforcement in a soil matrix, and the increase of shear strength parameters was verified. The plant fibers yielded a greater ductility and post-cracking strength for soil composites. In this context, the present work aims to evaluate the reinforced soil mechanical behaviour, emphasizing the fiber length and content influence.

\section{Materials and methods}

\subsection{Sandy soil}

The sandy soil was obtained in a commercial establishment and prepared in the laboratory, through a drying process in the kiln and pre-screening, in which the sieve No. $10(2.0 \mathrm{~mm})$ was used, the retained material was discarded. Aiming to obtain a uniform material with well defined and stable mechanical behaviour, in order to provide the best interpretation of the effects caused by the fiber addition.

The material is composed of $1.5 \%$ clay $(<0.002 \mathrm{~mm})$, $2.6 \%$ silt $(0.002-0.06 \mathrm{~mm})$ and $95.9 \%$ sand, of which $20.4 \%$ is fine sand $(0.06-0.2 \mathrm{~mm}), 52.7 \%$ medium sand $(0.2-0.6 \mathrm{~mm})$, and only $22.9 \%$ coarse sand $(0.6-2.0 \mathrm{~mm})$. The sandy soil presents uniform granulometry and according to the Unified Soil Classification System (USCS), being classified as a well-graded sand (SW). The material physical properties (Table 1) were determined at the Geotechnics Laboratory at the University of Brasília (UnB) in Brazil.

Table 1. Sandy soil physical properties. [1, 2, 3, 4]

\begin{tabular}{|c|c|c|}
\hline Property & Value & Test Method \\
\hline Grain density $\left(\mathrm{G}_{\mathrm{s}}\right)$ & 2.68 & $\begin{array}{c}\mathrm{ABNT} \\
6458: 2016[3]\end{array}$ \\
\hline Maximum void ratio $\left(\mathrm{e}_{\max }\right)$ & 0.89 & $\begin{array}{c}\mathrm{ABNT} \\
12051: 1991[1]\end{array}$ \\
\hline
\end{tabular}

\begin{tabular}{|c|c|c|} 
Minimum void ratio $\left(\mathrm{e}_{\mathrm{min}}\right)$ & 0.59 & ABNT \\
& & $12004: 1990[2]$ \\
\hline Coefficient of uniformity $\left(\mathrm{C}_{\mathrm{u}}\right)$ & 2.40 & ABNT \\
\cline { 1 - 2 } Coefficient of curvature $\left(\mathrm{C}_{\mathrm{c}}\right)$ & 1.07 & $7181: 2017$ [4] \\
\hline Effective grain size $\mathrm{D}_{10}(\mathrm{~mm})$ & 0.175 & \\
\hline
\end{tabular}

\subsection{Curauá fiber}

The fibers of curauá, of the species Ananas erectifolius, are fibers extracted from the leaves of the plant (Figure 1), which are of natural occurrence in the Amazon [15].

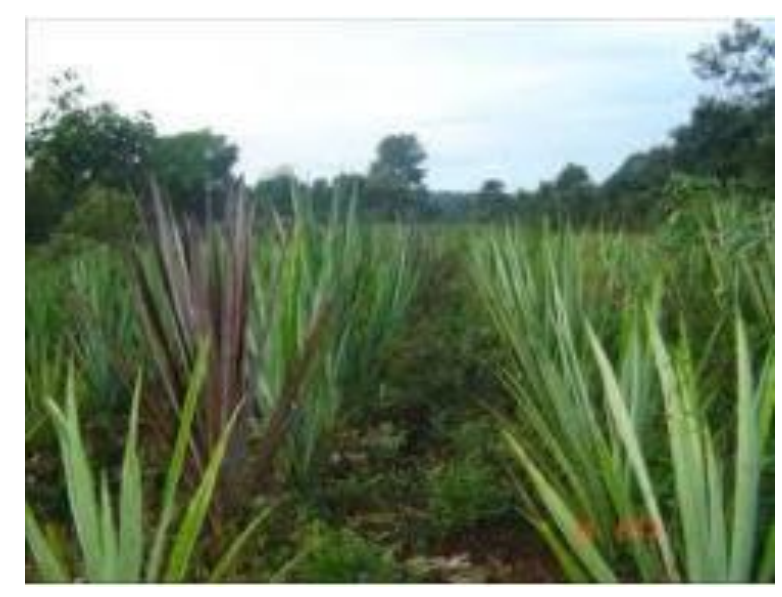

Fig. 1. Curauá Plantation [15].

The curauá fibers were commercially acquired by Pematec Triangel do Brasil, from the city of SantarémPA. Table 2 and Table 3 present values, available in the literature, for the physical and mechanical properties of the fiber, respectively.

Table 2. Curauá fiber physical properties. [6,11,12,15]

\begin{tabular}{|c|c|c|c|}
\hline $\begin{array}{c}\text { Diameter } \\
(\mathbf{m m})\end{array}$ & $\begin{array}{c}\text { Area } \\
\left(\mathbf{m m}^{\mathbf{2}}\right)\end{array}$ & $\begin{array}{c}\text { Density } \\
\mathbf{( g / \mathbf { c m } ^ { \mathbf { 3 } }}\end{array}$ & Reference \\
\hline 0.09 & - & - & {$[15]$} \\
\hline 0.115 & - & 1.29 & {$[12]$} \\
\hline $0.092-0.127$ & - & 1.34 & {$[11]$} \\
\hline- & 0.004 & - & {$[6]$} \\
\hline
\end{tabular}

Table 3. Curauá fiber mechanical properties. [6, 11, 15]

\begin{tabular}{|c|c|c|c|}
\hline $\begin{array}{c}\text { Tensile } \\
\text { strength } \\
\text { (MPa) }\end{array}$ & $\begin{array}{c}\text { Young's modulus } \\
\text { (GPa) }\end{array}$ & $\begin{array}{c}\text { Failure } \\
\text { strain (\%) }\end{array}$ & Reference \\
\hline 543.0 & 63.7 & 1.0 & {$[6]$} \\
\hline 605.0 & 23.0 & 2.5 & {$[15]$} \\
\hline 492.6 & 11.5 & 3.0 & {$[11]$} \\
\hline
\end{tabular}

\subsection{Sample preparation}

The specimens were molded inside the direct shear box, measuring $300 \times 300 \mathrm{~mm}$ in width and $200 \mathrm{~mm}$ in height. The test specimen is performed by manual compaction, with the help of a layered steel socket. The test specimen was divided into five layers of the sand-fiber composite in order to control the relative density of the sand-fiber 
composite. The soil-fiber weight is calculated according to the desired parameters, such as relative density and fiber content of the soil-fiber composite. The water content added was $10 \%$ in relation to the dry weight of the soil with a relative density of $50 \%$. Table 4 summarizes the fiber content and length used on the tests. It is worth mentioning that the curauá fibers were randomly arranged in the soil mass.

Table 4. Curauá fibers length and content.

\begin{tabular}{|c|c|}
\hline Fiber content $(\mathbf{\%})$ & Fiber length $(\mathbf{m m})$ \\
\hline 0 & - \\
\hline 0.50 & 25 \\
\hline 0.75 & 25 \\
\hline
\end{tabular}

\subsection{Direct shear tests}

The direct shear equipment of medium dimensions (Figure 2) used in the research was developed by Palmeira [10] until adaptation by Sánchez [13-14] at the Geotechnical Laboratory of the University of Brasília.

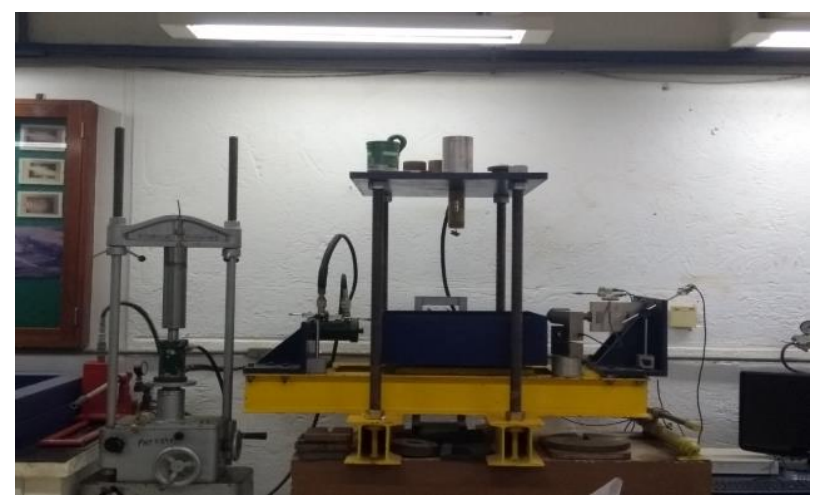

Fig. 2. Shear strength test apparatus

All direct medium-size shear tests were performed with reinforced and non-reinforced sandy matrix. The tests were performed with normal stresses of 25,50 and $100 \mathrm{kPa}$ at constant velocity of $0.508 \mathrm{~mm} / \mathrm{min}$ and maximum shear displacement of $40 \mathrm{~mm}$.

\section{Results}

Figure 3 presents the shear stress $\mathrm{x}$ horizontal displacement curves, for all normal stresses $(25,50$ or 100 $\mathrm{kPa}$ ). The curauá fibers were cut in lengths of $25 \mathrm{~mm}$, varying the fiber contents in 0.5 and $0.75 \%$. The curauá fibers were randomly arranged in the soil mass. The failure envelopes of the sandy soil and soil-fiber tests are shown in Figure 4.

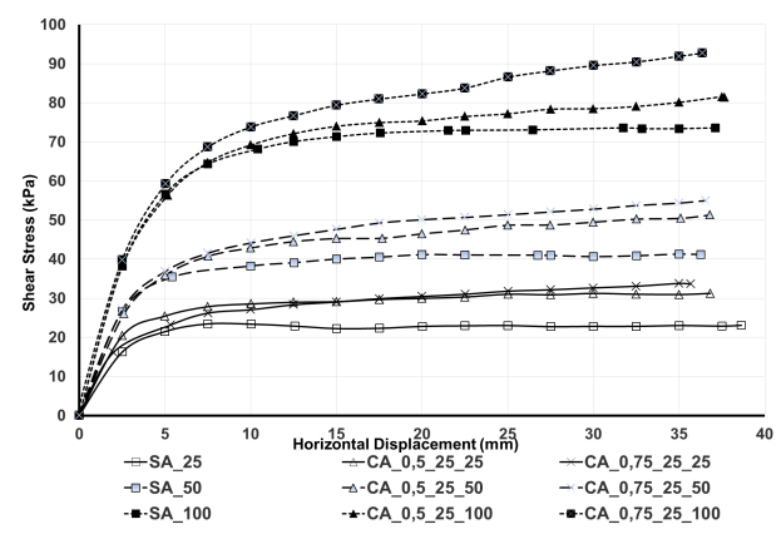

Fig. 3. Shear stress curves $x$ horizontal displacement for sandy soil and sand-fiber composite in the contents of $0.5 \%$ and $0.75 \%$ for 25,50 and $100 \mathrm{kPa}$ normal stresses.

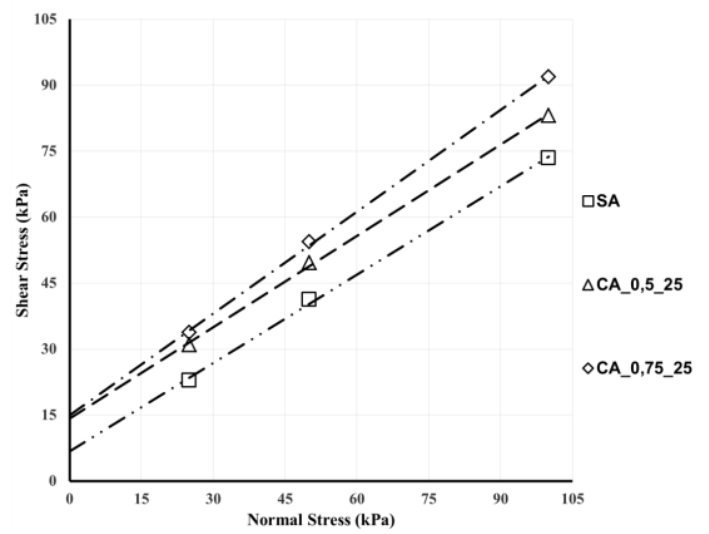

Fig. 4. Failure envelopes

It can be observed that the shear strength increases with the increase of the normal stress without presenting stress peaks for the three materials. The increase in shear strength due to the addition of the fibers in relation to the non-reinforced material can be observed, as well as with the increase of fiber content.

For the normal stress of $25 \mathrm{kPa}$, the soil-fiber composite presented an increase in the shear stress when compared with the sandy soil. It is worth mentioning that a negligible improvement was observed from the $0.50 \%$ and the $0.75 \%$ fiber content curve. For the normal stresses of $50 \mathrm{kPa}$ and $100 \mathrm{kPa}$, the soil-fiber composites showed an significant improvement in the shear stress with the increase of the fiber content. It is verified that the $0.75 \%$ fiber content curves presented the best results when evaluating the increase in shear stress of the material. It is also worth mentioning that the shear strength parameters also presented a considerable improvement.

In the process of mixing the sandy soil with the curauá fibers, it was observed that the fibers bonded with the soil grains, thus, promoting an anchoring effect. This effect was confirmed with the increase of the shear strength parameters, cohesion and friction angle of the material. The shear strength parameters of the sandy soil and the soil-fiber composite are presented in Table 5. 
Table 5. Shear strength parameters.

\begin{tabular}{|c|c|c|}
\hline Sample & $\begin{array}{c}\text { Cohesion } \\
\text { (kPa) }\end{array}$ & $\begin{array}{c}\text { Friction angle } \\
\text { (o) }\end{array}$ \\
\hline SA & 6 & 34 \\
\hline CA_0.5_25 & 15 & 34 \\
\hline CA_0.75_25 & 15 & 38 \\
\hline
\end{tabular}

\section{Conclusions}

This research presented the analysis of the mechanical behaviour of a sandy soil reinforced with natural fiber of curauá through direct shear tests in true magnitude. From the direct shear tests of medium dimensions performed in sandy soil and mixtures of soil-fiber of curauá with 25.0 $\mathrm{mm}$ length, fiber contents of 0.5 and $0.75 \%$ and with random disposition in the soil mass, a number of conclusions were observed as follows:

1. The samples of sandy soil with curauá fiber reinforcement presented an increase of shear stress with the increase of the normal stress. This increase is attributed to the anchoring effect caused by the fiber addition in the soil mass.

2. The addition of curauá fibers with $25.0 \mathrm{~mm}$ length and $0.75 \%$ content in the sandy soil matrix resulted in the highest shear stress value for the highest normal stress level $(100 \mathrm{kPa})$. For the evaluated fiber contents, the higher the content and the applied load, the greater the increase of mechanical resistance.

3. The inclusion of curauá fibers provided a reasonable increase in the shear strength parameters of the sandy soil, cohesion and friction angle of the material.

4. The results were satisfactory for the inclusion of natural fibers of curauá as soil reinforcement, with potential application in landfills on soft soils, slopes and shallow foundations, giving a better end to this material in the technical scope, also attending to economic, social and environmental aspects.

5. The behaviour of the soil-fiber mixtures in all the stress-displacement curves presents a similar aspect, the curves do not present a resistance peak.

6. In the failure envelopes for the sandy soil and soilfiber composite, with failure criterion at $35 \mathrm{~mm}$ of displacement, a significant increase in the shear strength parameters in all the mixtures was verified, the cohesive intercept and the frction angle presented an improvement of $150 \%$ and $11 \%$, respectively, compared with the sandy soil.

7. The sandy soil reinforced with curauá fiber presented a more significant increase in its cohesive interceptive. However, the friction angle presented a slight improvement. This phenomenon is observed on the specimen preparation process, when the curauá fiber is mixed with the sandy soil, it is observed that the fibers provide an aggregation with the soil grains, promoting an anchoring effect. From this observation, the notorious increase of the cohesive intercept can be justified.

8. The fiber content addition influence was analyzed taking into consideration the values of shear stress for a $35 \mathrm{~mm}$ displacement. For the $25 \mathrm{kPa}$ normal stress, the curauá fibers presented a shear stress increase of approximately $9 \%$. A shear stress increase of $7 \%$ was verified for a normal stress of $50 \mathrm{kPa}$. As for the 100 $\mathrm{kPa}$ normal stress, the curauá fibers addition presented a shear stress increase of approximately $15 \%$.

The authors thank the Coordination of Improvement of Higher Education Personnel - Brazil (CAPES) - Financing Code 001 for the financial support.

\section{References}

1. ABNT-NBR 12004: Solo - Determinação do índice de vazios máximo de solos não coesivos - Método de ensaio. Associação Brasileira De Normas Técnicas, Rio de Janeiro, p. 6. (1990)

2. ABNT-NBR 12051: Solo - Determinação do índice de vazios mínimo de solos não-coesivos - Método de ensaio. Associação Brasileira De Normas Técnicas, Rio de Janeiro, p. 15. (1991)

3. ABNT-NBR 6458: Grãos de pedregulho retidos na peneira de abertura 4,8 mm - Determinação da massa especifica, da massa especifica aparente e da absorção de água. Associação Brasileira De Normas Técnicas, Rio de Janeiro, p. 10. (2016)

4. ABNT-NBR 7181: Solo- Análise granulométrica. Associação Brasileira De Normas Técnicas, Rio de Janeiro, p. 12. (2017)

5. D. B. Dittenber, H. V. S. Gangarao,. Critical review of recent publications on use of natural composites in infrastructure. Composites Part A: Applied Science and Manufacturing, Elsevier, 43, 8, 1419-1429. (2012)

6. M. Fidelis,. Desenvolvimento e caracterização mecânica de compósitos cimentícios têxteis reforçados com fibras de juta. Tese ( Doutorado) Universidade Federal do Rio de Janeiro. Programa de Pós-graduação em Engenharia Civil, COPPE. (2014)

7. K., Ghavami, R. D. Tolêdo Filho, N. P. Barbosa,. Behaviour of composite soil reinforced with natural fibres. Cement and Concrete Composites, Elsevier, v. 21, n. 1, p. 39-48. (1999)

8. J. K. Mitchell, W.C.B. Villet,. Reinforcement of earth slopes and embankments. : NCHRP Rep. No. 290, Washington, D.C. (1987)

9. A. F. D. Oliveira,. Avaliação de desempenho de fibras lignocelulósicas na sorção de óleos diesel e biodiesel. Tese (Doutorado) - Universidade Estadual Paulista, Faculdade de Ciências Agronômicas, Botucatu, 98p. (2010)

10. E. M. Palmeira,. Equipamento Para Ensaios de Tração Confinada de Geotêxteis em Solos - Versão 2. Relatório de Pesquisa. Programa de PósGraduação em Geotecnia, Universidade de Brasília. (1998)

11. M. D. S. Picanço,. Compósitos cimentícios reforçados com fibras de curauá. Dissertação (Mestrado) - Centro Técnico Científico, Pontifícia 
Universidade Católica do Rio de Janeiro, Rio de Janeiro. (2005)

12. A. R. A. G. Pinto,. Fibras de curauá e sisal como reforço em matrizes de solo. Dissertação (Mestrado) - Departamento de Engenharia Civil, Pontifícia Universidade Católica do Rio de Janeiro, 103p. (2007)

13. N. P. Sánchez, G. L. S. Araújo, E. M. Palmeira,. Estudo Multi-escala da Resistência ao Cisalhamento da Interface entre Geotêxtil Não Tecido e Solo. COBRAMSEG 2016. ABMS, Belo Horizonte. (2016)

14. N. P. Sánchez, Estudo de alguns aspectos que influenciam a aderência entre geossintéticos $e$ diferentes materiais. Tese de Doutorado. Programa de Pós-Graduação em Geotecnia, Departamento de Engenharia Civil e Ambiental, Universidade de Brasília, 168p. (2018)

15. G. A. Santiago,. Estudo do Comportamento Mecânico de Compósitos SoloFibras Vegetais Impermeabilizadas com Solução de Poliestireno Expandido (EPS) e Cimento Asfáltico de Petróleo $(C A P)$. Tese de Doutorado. Rede Temática em Engenharia de Materiais, Universidade Federal de Ouro Preto, 130p. (2011)

16. P. A. Santos,. Efeito da forma de processamento e do tratamento da fibra de curauá nas propriedades de compósitos com poliamida-6. Polímeros: Ciência e tecnologia, Associação Brasileira de Polímeros, 19, 1. (2009)

17. M. V. Silveira,. Análise do Comportamento Mecânico e da Durabilidade em Compósitos de Areia Reforçada com Fibras Naturais de Curauá e Sisal. Tese de Doutorado. Programa de Pós-graduação em Engenharia Civil da PUC-Rio. Rio de Janeiro. Brasil. 148p. (2018)

18. F. Tomczak, K. G. Satyanarayana, T. H. D. Sydenstricker,. Studies on lignocellulosic fibers of brazil: Part iii-morphology and properties of Brazilian curauá fibers. Composites Part A: Applied Science and Manufacturing. Elsevier. 38, 10, 22272236 (2007) 